\title{
In Planta Quantification of Plasmodiophora brassicae Using Signature Fatty Acids and Real-Time PCR
}

Thomas Sundelin, Department of Plant Biology and Biotechnology, Faculty of Life Sciences, University of Copenhagen, Thorvaldsensvej 40, DK-1871 Frederiksberg, Denmark; Camilla Beck Christensen, Department of Plant Biology and Biotechnology, Faculty of Life Sciences, University of Copenhagen, and Department of Integrated Pest Management, Faculty of Agricultural Sciences, University of Aarhus, Forsøgsvej 1, DK-4200 Slagelse, Denmark; John Larsen and Kaare Møller, Department of Integrated Pest Management, Faculty of Agricultural Sciences, University of Aarhus; Mette Lübeck, Section for Sustainable Biotechnology, Department of Biotechnology, Chemistry and Environmental Engineering, Copenhagen Institute of Technology, Aalborg University, Lautrupvang 15, DK-2750 Ballerup, Denmark; Lars Bødker, Department of Integrated Pest Management, Faculty of Agricultural Sciences, University of Aarhus; and Birgit Jensen, Department of Plant Biology and Biotechnology, Faculty of Life Sciences, University of Copenhagen, and Department of Integrated Pest Management, Faculty of Agricultural Sciences, University of Aarhus

\begin{abstract}
Sundelin, T., Christensen, C. B., Larsen, J., Møller, K., Lübeck, M., Bødker, L., and Jensen, B. 2010. In planta quantification of Plasmodiophora brassicae using signature fatty acids and realtime PCR. Plant Dis. 94:432-438.

Until now, molecular and biochemical methods have only been used to show whether or not Plasmodiophora brassicae is present in plant or soil samples but not to what extent. Here, in planta quantification of $P$. brassicae by whole-cell fatty acid (WCFA) measurements and realtime polymerase chain reaction (PCR) was evaluated. Arachidonic acid (ARA, 20:4) was the most abundant fatty acid in resting spores and was only found in infected roots, which indicates a potential of ARA as a biomarker for P. brassicae. A real-time PCR assay was developed using primers designed from the internal transcribed spacer region of the ribosomal DNA. Using these primers, it was possible to detect $P$. brassicae in infected roots 10 days after germination of plants sown in infested soil. A bioassay showed that the amounts of ARA found by WCFA analysis and the DNA found by real-time PCR in infected plants were well correlated. These measurements also correlated with the soil spore content and the assessed disease incidence and disease severity scores. Therefore, we conclude that WCFA analysis and real-time PCR are good tools for $P$. brassicae quantification that can be applied to basic studies of the pathogen and in resistance screens.
\end{abstract}

Clubroot, caused by the soilborne obligate parasite Plasmodiophora brassicae, is considered one of the economically most important diseases of cruciferous crops (15). In spring oilseed rape (Brassica napus) yield losses of 10 to $50 \%$ have been reported and the pathogen is estimated to be present in approximately $10 \%$ of the Brassica-cultivated area worldwide (2,34). Besides being widespread, the resting spores are long lived, making the pathogen difficult to control (33). A variety of methods have been developed for $P$. brassicae detection and quantification, all of them with a number of drawbacks (7). Bioassays, in which plants are sown in infested soil $(5,18)$, are labor intensive and both space and time consuming. Counting the number of root hair infections (16) or the

Corresponding author: T. Sundelin

E-mail: tsu@life.ku.dk

Accepted for publication 11 December 2009.

doi:10.1094/PDIS-94-4-0432

(c) 2010 The American Phytopathological Society number of stained resting spores in a soil sample (26) requires skilled personnel. Spore numbers have been estimated in plant samples through measurements of chitin, using a colorimetric assay (27). Serological methods, such as dot-blot, enzyme-linked immunosorbent assay (ELISA), and immunofluorescence have been shown to work $(11,32)$ but are rarely used. Recently, engineered fluorescent Papaya mosaic virus (PapMV) virus-like particles (VLPs) were shown to bind to $P$. brassicae resting spores at least as efficiently as polyclonal antibodies. The PapMV VLPs are easily produced in high yields; hence, they could possibly form a basis for a new type of detection method (19).

Several polymerase chain reaction (PCR)-based assays have been developed for detection of $P$. brassicae $(4,6,9,35)$. The detection primers for $P$. brassicae have been designed to amplify either a single-copy sequence $(9,35)$ or the multicopy ribosomal DNA (rDNA) $(4,6)$. Wallenhammar and Arvidsson (35) evaluated different primers and found that the sensitivity of the primers could be up to
1,000 times better if nested PCR was used instead of standard PCR. The same study also revealed no apparent difference in sensitivity between primers amplifying rDNA and those amplifying the singlecopy sequence. In general, the sensitivity is very good and amounts as low as $0.1 \mathrm{fg}$ of pure $P$. brassicae DNA can be detected (6). Using DNA extracted from artificially infested soils, the detection limit has been reported to be $1 \times 10^{3}$ spores/g of soil $(4,6)$. In the related plant pathogens Spongospora subterranea and Polymyxa graminis, real-time PCR has been shown to be more sensitive than conventional PCR and ELISA $(23,30,36)$. This is consistent with the general assumption that, for root pathogens, the detection limit may be measured in femtograms for purified plant pathogen DNA and in picograms for infected plant samples, using real-time PCR (20).

Biomarker fatty acids have been developed for in planta quantification of rootliving microorganisms such as 16:1 105 and $14: 1 \omega 9$ specific for arbuscular mycorrhizal (AM) fungi (21) and the root pathogen Aphanomyces euteiches (13), respectively. These biomarker fatty acids have been used to study interactions between AM fungi and $A$. euteiches $(12,28)$. In addition, $16: 1 \omega 5$ can be used to estimate biomass or inoculum potential of AM fungi in soil (21). Arachidonic acid (ARA; 20:4) is another potential biomarker fatty acid found in different root-living microorganisms such as chytrids (37), peronosporomycetes (8,13), AM fungi (21), plasmodiophorids such as $S$. subterranea (J. Larsen, unpublished), and other protozoans (14).

To our knowledge, neither biochemical nor molecular methods have been developed for quantification of Plasmodiophora brassicae in roots or soil during the entire lifecycle of the pathogen. Such methods would make it possible to give precise and objective measures of $P$. brassicae root infection level and biomass estimates, which can be used in basic studies of the 
biology of the pathogen and when screening for plant resistance or during development of other control measures.

The objective of this study was to evaluate the possibilities of in planta quantification of $P$. brassicae by real-time PCR and by whole-cell fatty acid (WCFA) analysis, using the fatty acid ARA as a biomarker. The performance of the two methods was compared with disease incidence (DI) and disease severity score (DSS) assessments.

\section{MATERIALS AND METHODS}

Preparation of resting spore inoculum. Infected Chinese cabbage ( $B$. rapa subsp. pekinensis) roots showing severe clubroot symptoms were collected from a Danish cabbage field (K. Vincent, Bisserup, Denmark) heavily infested with $P$. brassicae, and the clubbed roots were subsequently washed and stored at $-18^{\circ} \mathrm{C}$. The frozen roots were crushed, mixed with sterile water, blended for approximately 3 min (Ultra-Turrax DI 25 basic; IKA, Staufen, Germany), and filtered through gauze followed by filtration through $30-\mu \mathrm{m}$ nylon mesh. The suspension was centrifuged at 2,500 $\times \mathrm{g}$ for $5 \mathrm{~min}$ and the supernatant was discarded. Pellets were washed with sterile water and centrifuged three times as described above. Finally, pellets were resuspended in sterile water and the concentration of $P$. brassicae spores was determined using a hemacytometer. The spore suspensions were kept at $5^{\circ} \mathrm{C}$ until use.

Soil bioassay. Field soil was sterilized with dry heat at $110^{\circ} \mathrm{C}$ for $24 \mathrm{~h}$ and mixed with quartz sand 1:1 (wt/wt). The following minerals were mixed into the soil mixture: $\mathrm{NH}_{4} \mathrm{NO}_{3}\left(86 \mathrm{mg} \mathrm{kg}^{-1}\right.$ of soil), $\mathrm{KH}_{2} \mathrm{PO}_{4}$ (44 mg kg-1 of soil), $\mathrm{K}_{2} \mathrm{SO}_{4}$ (70 $\mathrm{mg} \mathrm{kg}$ of soil), $\mathrm{CaCl}_{2}$ (70 $\mathrm{mg} \mathrm{kg}^{-1}$ of soil), $\mathrm{CuSO}_{4} \times 5 \mathrm{H}_{2} \mathrm{O}\left(2.2 \mathrm{mg} \mathrm{kg}^{-1}\right.$ of soil), $\mathrm{ZnSO}_{4} \times 7 \mathrm{H}_{2} \mathrm{O}\left(5 \mathrm{mg} \mathrm{kg}^{-1}\right.$ soil), $\mathrm{MnSO}_{4} \times$ $7 \mathrm{H}_{2} \mathrm{O}\left(10 \mathrm{mg} \mathrm{kg}^{-1}\right.$ of soil $), \mathrm{CoSO}_{4} \times 7 \mathrm{H}_{2} \mathrm{O}$ (0.33 mg kg-1 of soil), $\mathrm{NaMoO}_{4}(0.2 \mathrm{mg}$ $\mathrm{kg}^{-1}$ of soil), and $\mathrm{MgSO}_{4} \times 7 \mathrm{H}_{2} \mathrm{O}(20 \mathrm{mg}$ $\mathrm{kg}^{-1}$ of soil). Spore suspensions $(100 \mathrm{ml})$ were mixed into $1-\mathrm{kg}$ portions of the soil mixture and filled in $1,600-\mathrm{ml}$ pots. The following densities of $P$. brassicae resting spores per gram of soil were obtained: 0 , $1.0 \times 10^{2}, 2.0 \times 10^{2}, 2.6 \times 10^{2}, 7.8 \times 10^{2}$, $9.4 \times 10^{2}, 1.6 \times 10^{3}, 2.0 \times 10^{3}, 4.7 \times 10^{3}$, $7.8 \times 10^{3}, 1.0 \times 10^{4}, 4.7 \times 10^{4}, 1.4 \times 10^{5}$, and $1.0 \times 10^{6}$. Ten seeds of oilseed rape cv. Caracas were sown in each pot and, subsequently, the pots were watered to $75 \%$ of field capacity. Four replicates per treatment were randomized in four blocks and placed on a greenhouse bench. Natural daylight was supplemented with $16 \mathrm{~h}$ of light per day from Osram daylight lamps providing a minimum of $150 \mu \mathrm{mol}$ of photosynthetically active radiation (PAR) $\mathrm{m}^{-2}$ $\mathrm{s}^{-1}$. Minimum day and night temperatures were 20 and $16^{\circ} \mathrm{C}$, respectively. One week after germination, the number of plants was reduced to six plants per pot.
In order to determine how early infection could be detected using real-time PCR, another bioassay was carried out. Quartz sand $(1 \mathrm{~kg})$ was inoculated with $200 \mathrm{ml}$ of spore suspension $\left(0,5.0 \times 10^{3}\right.$, and $1.0 \times 10^{6}$ spores/g of soil) and filled in 800 -ml pots. Each spore concentration was made in four replications. Ten seeds of Chinese cabbage cv. Granaat were sown in each pot. The pots were placed in a growth chambers with $16 \mathrm{~h}$ of light (Philips TL-D Deluxe 36W/950, $200 \mu \mathrm{mol}$ PAR $\mathrm{m}^{-2} \mathrm{~s}^{-1}$ ) and $8 \mathrm{~h}$ of darkness. Day and night temperatures were maintained at 20 and $15^{\circ} \mathrm{C}$, respectively. Roots were harvested in liquid $\mathrm{N}_{2}$ at 10,15,25, and 35 days after sowing and stored at $-80^{\circ} \mathrm{C}$. This experiment was carried out twice.

Disease assessment and fresh weight measurements. Oilseed rape plants were harvested and the roots were washed 35 days after sowing. The number of plants with clubroot symptoms was determined and DI was assessed for each replication. DSSs were assessed, using a scale with four classes modified after Buczacki et al. (3) and Voorrips and Kanne (31), where 0 = no symptoms, $1=$ swollen main root or small sporadic attack with clubs $<2 \mathrm{~mm}, 2$ $=$ clubs $\leq 6 \mathrm{~mm}$, and $3=$ clubs $>6 \mathrm{~mm}$ or clubs account for more than half of the root system. Following disease assessment, roots were cut from shoots with a scalpel and their fresh weights were determined. Shoots were dried at $80^{\circ} \mathrm{C}$ for $24 \mathrm{~h}$ before recording the shoot dry weight. Subsequently, roots were lyophilized for $24 \mathrm{~h}$ $\left(0.5 \mathrm{hPa},-85^{\circ} \mathrm{C}\right)$ and pulverized in a steel mill. The plant material was stored at $-20^{\circ} \mathrm{C}$.

WCFA analysis of resting spores and roots. WCFA were extracted from the pulverized root samples $(25 \mathrm{mg})$ from the soil bioassay described above $(n=4)$ and from resting spores used as $P$. brassicae inoculum $(n=2)$ employing a four-step fatty acid extraction procedure according to a method by Sasser (24): (i) saponification, (ii) methylation, (iii) extraction, and (iv) base wash. To enable quantification of the extracted fatty acid methyl esters, an internal standard, nonadeconoate fatty acid methyl ester, was added to each sample. Analyses of fatty acid methyl esters were performed using the software package Sherlock (version 6.0; MIDI Inc., Newark, DE) with an HP Chemstation (Hewlett Packard, Pablo Alto, CA) and an HP6890 GC fitted with a 25-m fused silica capillary column (HP part no. 19091B-102) and hydrogen as carrier gas. The injector temperature was $250^{\circ} \mathrm{C}$ and the detector temperature was $300^{\circ} \mathrm{C}$. The temperature program was as follows: initial temperature of $170^{\circ} \mathrm{C}$ increasing to $270^{\circ} \mathrm{C}$ at $5^{\circ} \mathrm{C} / \mathrm{min}$. In all, $2 \mu \mathrm{l}$ per sample was injected. The MIDI software automatically controlled all gas chromatography operations, including calibration, subsequent sample sequencing, peak integration, and naming. Calibration standards contained a mixture of straightchain saturated and hydroxy fatty acid methyl esters with a length of 10 to 20 carbon (MIDI part mo. 1200A).

DNA extraction. Genomic DNA was extracted from $100 \mathrm{mg}$ of the lyophilized or frozen plant material mentioned above, using the DNeasy Plant Mini Kit (Qiagen, Hilden, Germany) following the manufacturer's instructions.

Pure $P$. brassicae DNA used to prepare standard series in real-time PCR was extracted from resting spores prepared from clubbed roots as described above. The extracted spores were washed at least three times with sterile water. Streptomycin was added to a concentration of $100 \mu \mathrm{g} / \mathrm{ml}$ in order to limit bacterial growth. The isolated spores were treated with DNase I (100 U/ml) (New England Biolabs, Ipswich, MA) in $1 \times$ DNase I reaction buffer (10 mM Tris- $\mathrm{HCl}, 2.5 \mathrm{mM} \mathrm{MgCl}_{2}$, and 0.5 $\mathrm{mM} \mathrm{CaCl}_{2}$ ) for $6 \mathrm{~h}$ at $37^{\circ} \mathrm{C}$ to remove plant DNA contamination. The DNase I was heat inactivated at $75^{\circ} \mathrm{C}$ for $10 \mathrm{~min}$. The spores were washed with sterile water and lyophilized before DNA extraction using the DNeasy Plant Mini Kit (Qiagen). All DNA concentrations were measured using the NanoDrop ND-1000 (Nanodrop Technologies, Wilmington, DE).

Real-time PCR analysis of roots. The internal transcribed spacer (ITS) region of $P$. brassicae was assessed from GenBank (Y12831) and used for designing the primer Pb4-1 (TACCATACCCAGGGC GATT) using Primer3 (http://frodo.wi.mit. edu/primer3/). After design of the primer, it was checked by alignment that the primer sequence was found in all P. brassicae ITS sequences available in GenBank. This primer was used in combination with the primer PbITS6 (CAACGAGTCAGC TTGAATGC) (6). In combination, the two primers amplify a 139-bp fragment of the ITS region. PCR was performed using the real-time PCR system Mx3000P (Stratagene, La Jolla, CA). Each reaction of 25 $\mu \mathrm{l}$ contained $10 \mathrm{ng}$ of genomic DNA, 10 pmol of each primer, $12.5 \mu \mathrm{l}$ of $2 \times$ SYBR Green master mix (Stratagene), and $0.4 \mu \mathrm{l}$ of a 1,000x diluted reference dye (Stratagene). The PCR reaction was set up in triplicate for each DNA sample. A standard series made with serial diluted pure $P$. brassicae DNA of known concentration was included on each plate. In addition, a similar standard series was used to determine the minimum amount of pure $P$. brassicae DNA that could be detected using real-time PCR. Prior to amplification, an initial denaturation step was performed $\left(95^{\circ} \mathrm{C}\right.$ for $\left.10 \mathrm{~min}\right)$ ensuring complete denaturation of the DNA and activation of the Taq polymerase. This was followed by 40 cycles of $15 \mathrm{~s}$ at $95^{\circ} \mathrm{C}, 30 \mathrm{~s}$ at $58^{\circ} \mathrm{C}$, and $30 \mathrm{~s}$ at $72^{\circ} \mathrm{C}$. Fluorescence was detected after each cycle. After amplification, a melting curve analysis was performed in order to ensure that only one 
PCR product was amplified and the PCR product was sequenced by MWG Biotech, Eberberg, Germany.

Data analysis. Comparison of the WCFA composition of Chinese cabbage roots with and without $P$. brassicae infection was done by one-way analysis of variance of the individual fatty acids (arc sine transformed). Data on plant growth parameters (root and top weight), disease development (DI and DSS), and P. brassicae quantification (WCFA analysis and real-time PCR) were subjected to analysis of variance assuming a normal distribution. Treatment variances were stabilized by appropriate transformation of data, if necessary, and treatment means were separated by least significant difference values. Correlations between methods of disease assessment, quantification of $P$. brassicae DNA and ARA, and the plant growth parameters were tested using Kendall tau correlation. Hypotheses were rejected at $P$ $\leq 0.05$. All data were analyzed by PC-SAS (release 8.02; SAS Institute, Cary, NC).

\section{RESULTS}

Effect of $P$. brassicae spore concentration on root and shot weight. The soil spore concentration did not influence the fresh weight of the root significantly (Fig. 1A) because no significant difference was observed between the noninfested control and any of the treatments with a higher spore concentration. On the other hand, a significant decrease in the shoot dry weight was observed at increasing spore concentrations (Fig. 1B). However, the shoot dry weight of the noninfested control did not differ significantly from plants grown at spore concentrations up to 780 spores/g of soil.

Effect of $P$. brassicae spore concentration on DI and DSS. At the lowest spore concentration, $8 \%$ of the plants had visible disease symptoms, although not significantly different from the noninfested control. DI increased with increasing spore concentration until all plants were visibly infected at spore concentrations above $2 \times$ $10^{3}$ spores/g of soil (Fig. 2A).
At low spore concentrations, up to 200 spores/g of soil, the DSS was not significantly different from the noninfested control. (Fig. 2B). At higher spore concentrations, the DSS increased with increasing spore concentrations, and a highly positive and significant linear correlation between the DSS and the spore concentration $(r=$ $0.957, P<0.001)$ was seen.

WCFA analysis of $P$. brassicae resting spores and of infected roots. The predominant fatty acids in resting spores of $P$. brassicae were $16: 0,18: 1 \omega 9 ; 18: 1 \omega 7$, and 20:4 (Table 1), accounting for $80 \%$ of the total amount of fatty acids present in $P$. brassicae spores. ARA (20:4) was the single most abundant fatty acid, constituting $36 \%$ of the total amount of fatty acids. In roots, the amount of ARA increased with increasing spore concentration in the soil from $1.6 \times 10^{3}$ spores/g of soil (Fig. $3)$. Below this threshold, ARA levels did not vary significantly with changes in spore concentrations. The highest ARA amount measured was $6,970 \mathrm{nmol} / \mathrm{g}$ at $1 \times$
A

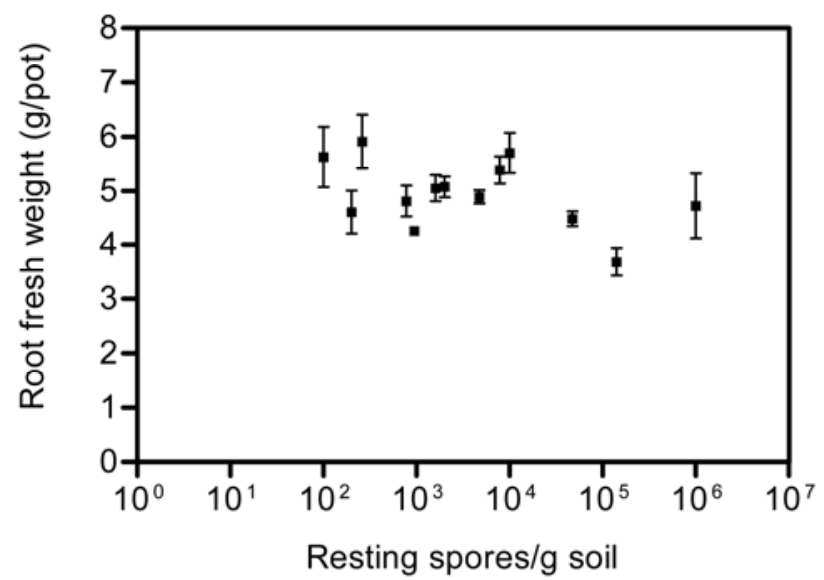

B

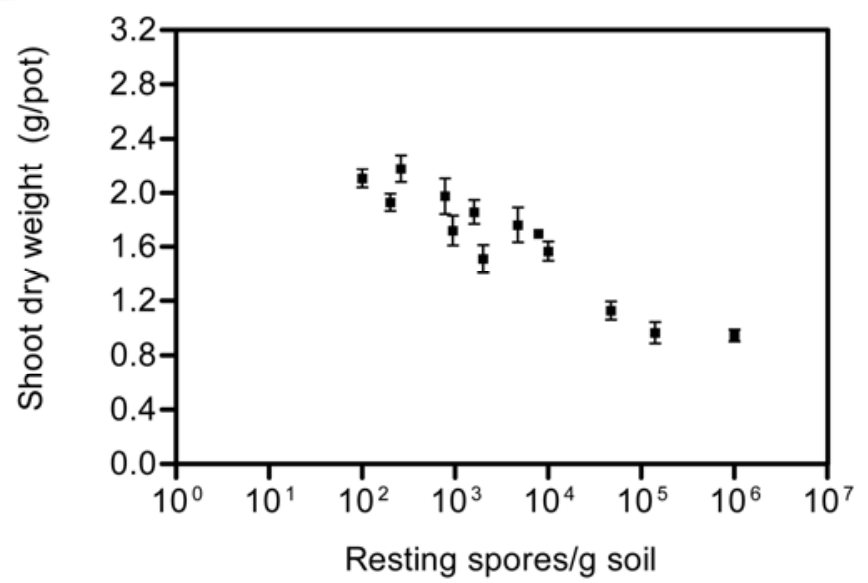

Fig. 1. Weight measurements of oilseed rape (cv. Caracas) plants sown in Plasmodiophora brassicae-infested soil with increasing soil spore concentrations. Plants were harvested and weighed 35 days after sowing. A, Root fresh weight measurement. B, Shoot dry weight measurement.

A

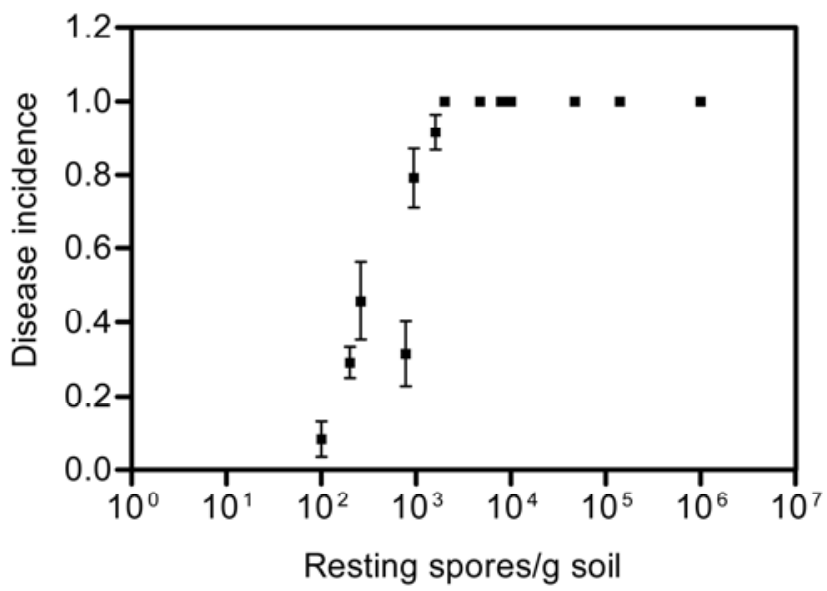

B

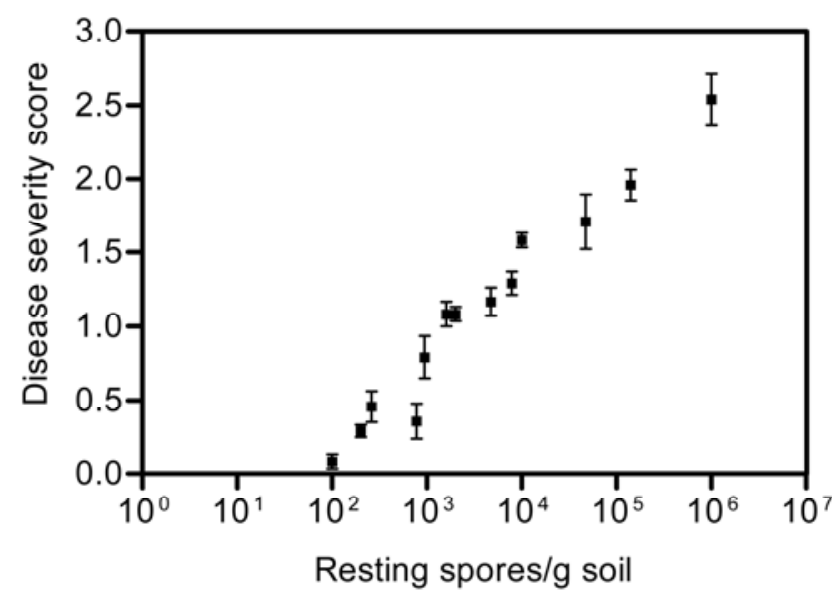

Fig. 2. Assessment of disease incidence and disease severity score of oilseed rape (cv. Caracas) plants sown in Plasmodiophora brassicae-infested soil with increasing soil spore concentrations. Assessment was made 35 days after sowing. Disease severity score was assessed using a four-class scale ranging from 0 (no symptoms) to 3 (clubs $>6 \mathrm{~mm}$ ). A, Disease incidence. B, Disease severity score. 
$10^{6}$ spores/g of soil. ARA was not detected in roots from the control treatment without addition of $P$. brassicae spores.

Real-time PCR analysis of $P$. brassicae-infected roots. The primer pair $\mathrm{Pb} 4-$ 1/PbITS6 amplified one PCR product using DNA from resting spores or infected plant roots (Fig. 4A). Sequencing analysis of this product revealed only one nucleotide difference between the amplified PCR product and the corresponding region of the GenBank accession Y12831 originally used for the primer design, confirming that it was of $P$. brassicae origin. The sequence has been deposited in GenBank under accession number GU181271. The PCR primers did not amplify a product using DNA from the control plants. There was a linear relation between the cycle threshold values and the $\log _{10}$ of the $P$. brassicae DNA concentration in the samples $(y=$ $-3.268 \log _{10}[x]+34,98 ; r^{2}=0.9992$; Fig. 4B). The lowest detectable amount of pure $P$. brassicae DNA was found to be $4.1 \mathrm{fg}$.

The measured amounts of $P$. brassicae DNA increased with increasing soil spore concentrations up to $4.7 \times 10^{4}$ spores/g of soil. At higher spore concentrations, no significant differences in the measured amounts of $P$. brassicae DNA were observed (Fig. 4C). The highest amount of $P$. brassicae DNA measured was $1.25 \mathrm{ng}$ of the $10 \mathrm{ng}$ of total DNA added to the PCR reaction. $P$. brassicae infection could be detected at the earliest time point assessed (i.e., 10 days after sowing Chinese cabbage in infested sand at both $5 \times 10^{3}$ and $1 \times 10^{6}$ spores/g of soil; Fig. 4D). The infection was also detected at the later time points (data not shown).

Comparison of methods. All methods used to estimate effects of $P$. brassicae at increasing soil spore concentration were significantly correlated $(P<0.0001$; Table 2 ), except the root weight measurement (data not shown). The shoot weight measurement was negatively correlated with the four other methods $(r=-0.5630$ to $-0.6553)$. The correlation between DI and the other methods was high, with the highest correlation between the DI and the DSS (0.8321). The real-time PCR had a high positive correlation with both DSS ( $r=$ $0.7586)$ and WCFA measurements ( $r=$ $0.7964)$, and DSS and WCFA measurements were also highly correlated $(r=$ 0.8013).

\section{DISCUSSION}

The results clearly show that real-time PCR and WCFA measurements can be used for in planta quantification of $P$. brassicae. To our knowledge, this is the first study testing the possibility of employing biomarker fatty acids for quantification of $P$. brassicae. We found that the amount of $P$. brassicae DNA measured by real-time PCR and the amount of the signature fatty acid ARA found by WCFA analysis were well correlated. The real- time PCR and signature fatty acid measurements not only correlated well to each other but also to DI, DSS, and soil spore concentration. Hence, it seems that realtime PCR and measurements of the fatty acid ARA are both good tools for in planta quantification of $P$. brassicae. Both methods can be useful as objective measures of $P$. brassicae root infection levels and biomass estimates necessary for basic studies of pathogen biology, such as responses to different environmental conditions or interactions with other organisms. Because the methods are sensitive, they may also be applied to screenings for plant resistance.

Although both DI and DSS are prone to subjectivity associated with visual symptom estimation, real-time PCR and WCFA analysis can be considered objective testing methods and, therefore, more precise. DI and DSS have, until now, been the only choices when levels of infection need to be estimated. Serological methods could be an alternative to real-time PCR and WCFA but their success depends on the specificity of the antibodies. Several serological assays has been developed over time $(11,32)$ but none of them are widely used. Recently, promising monoclonal antibodies have been produced (7). These antibodies might be good for the detection of P. brassicae but they have not yet been shown to be able to quantify the pathogen.

The fatty acid ARA was specific for $P$. brassicae-infected roots. Theoretically, ARA could originate from the plant as a response to $P$. brassicae infection but, because ARA is also found as an important constituent in $P$. brassicae resting spores, ARA in infected roots is most likely of unique pathogen origin. The WCFA analysis did not have the same sensitivity as real-time PCR. This problem may be overcome by refining the sample concentration technique. In this study, ARA worked well as a biomarker fatty acid for P. brassicae in a controlled experimental setup, showing high correlation with the other methods

Table 1. Percent fatty acid composition of roots of Chinese cabbage without and with Plasmodiophora brassicae infection $\left(10^{6}\right.$ resting spores per gram of soil) and of purified spores of P. brassicae ${ }^{y}$

\begin{tabular}{lccc}
\hline Fatty acids $^{\mathbf{z}}$ & Roots $-\boldsymbol{P}$. brassicae & Roots + P. brassicae & P. brassicae spores \\
\hline $16: 0$ & $22.2 \mathrm{a}$ & $23.4 \mathrm{a}$ & 14.9 \\
$18: 3 \omega 6.9 .12$ & $2.6 \mathrm{a}$ & $1.5 \mathrm{~b}$ & 1.2 \\
$18: 1 \omega 9$ & $32.9 \mathrm{a}$ & $35.8 \mathrm{a}$ & 20.8 \\
$18: 1 \omega 7$ & $0 \mathrm{a}$ & $6.0 \mathrm{~b}$ & 8.6 \\
$18: 0$ & $2.0 \mathrm{a}$ & $2.3 \mathrm{a}$ & 1.0 \\
11 methyl $18: 1 \omega 7$ & $3.6 \mathrm{a}$ & $0.5 \mathrm{~b}$ & 0.1 \\
$19: 0$ cyclo $\omega 8$ & $1.8 \mathrm{a}$ & $0.4 \mathrm{~b}$ & 0 \\
$18: 0$ 2OH & $3.7 \mathrm{a}$ & $0.9 \mathrm{~b}$ & 0 \\
$\mathbf{2 0 : 4 \omega 6 . 9 . 1 2 . 1 5}$ & $\mathbf{0 ~ a}$ & $\mathbf{7 . 5} \mathbf{~ b}$ & $\mathbf{3 6 . 5}$ \\
$20: 0$ iso & $0 \mathrm{a}$ & $1.5 \mathrm{~b}$ & 2.2 \\
$20: 1 \omega 9$ & $0.1 \mathrm{a}$ & $0 \mathrm{~b}$ & 2.1 \\
$20: 0$ & $5.8 \mathrm{a}$ & $2.0 \mathrm{~b}$ & 0 \\
Feature 3 & $2.5 \mathrm{a}$ & $2.2 \mathrm{~b}$ & 2.7 \\
Feature 5 & $14.5 \mathrm{a}$ & $12.9 \mathrm{~b}$ & 5.6 \\
Feature 7 & $5.0 \mathrm{a}$ & $1.1 \mathrm{~b}$ & 0 \\
\hline
\end{tabular}

${ }^{y}$ Fatty acids present in less than $1 \%$ in all samples are not included. Individual fatty acids with different letters are present in significant different amounts in roots with and without $P$. brassicae. Content of arachidonic acid (20:4 $\omega 6.9 .12 .15)$ is shown in bold.

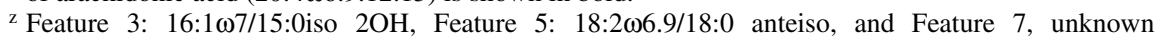

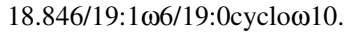

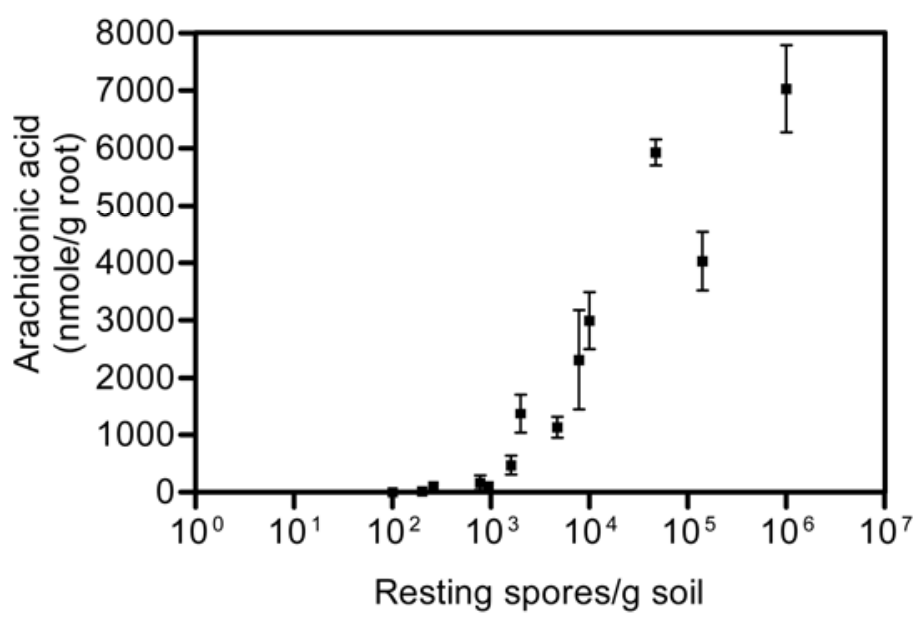

Fig. 3. Content of the biomarker fatty acid Arachidonic acid in oilseed rape (cv. Caracas) plants sown in Plasmodiophora brassicae-infested soil with increasing soil spore concentrations. Measurements were made 35 days after sowing. 
employed as well as with the spore density in soil. Similarly, ARA has been used as a sensitive biomarker examining the susceptibility of a broad range of Brassicae plant species toward P. brassicae (J. Larsen, unpublished data), suggesting that ARA can be employed as a fast and objective measure when screening for plant resistance against $P$. brassicae under controlled greenhouse conditions. However, because ARA is found in a range of microorganisms $(8,13,14,21,37)$, it will most likely not work equally well under field conditions with complex microbial communities.

One major advantage of the fatty-acidbased method is that measurements of different classes of fatty acids instead of WCFA can potentially provide detailed information of the pathogen biomass and the amount of storage lipids in the pathogen. Phospholipid fatty acids (PLFAs) are found in biological membranes and, there- fore, are excellent for estimations of biomass because biovolume and cell surface are well correlated (29). Neutral lipid fatty acids (NLFAs) serve as energy and NLFA/PLFA ratios can provide information on the nutritional status of the pathogen (1). Another advantage of fatty-acidbased methods is that information on other microorganisms is simultaneously provided, such as biomarkers of gramnegative and gram-positive bacteria as well as actinomycetes (22), which may be useful in studies of $P$. brassicae ecology.

Several PCR-based assays have been developed for detection of $P$. brassicae $(4,6,9,35)$ but, until now, only one of these is based on real-time PCR (25). In contrast to Schuller and Ludwig-Müller (25), who designed the primers $\mathrm{Pb}$-act1 and $\mathrm{Pb}$-act2 for the actin gene, we designed primers in the ITS region. This multiple-copy region of the rDNA has been shown to have ap-

Table 2. Correlation coefficients for comparison of different methods for quantification of Plasmodiophora brassicae: shoot weight, disease index (DI), disease severity score (DSS), whole-cell fatty acid analysis (WCFA), and real-time polymerase chain reaction (PCR) ${ }^{\mathrm{z}}$

\begin{tabular}{lccccc}
\hline & Shoot weight & DI & DSS & WCFA & Real-time PCR \\
\hline Shoot weight & 1 & $\ldots$ & $\ldots$ & $\ldots$ & $\ldots$ \\
DI & -0.5630 & 1 & $\ldots$ & $\ldots$ & $\ldots$ \\
DSS & -0.6277 & 0.8321 & 1 & $\ldots$ & $\ldots$ \\
WCFA & -0.6553 & 0.7223 & 0.8013 & 1 & $\ldots$ \\
Real-time PCR & -0.6037 & 0.6225 & 0.7586 & 0.7964 & 1 \\
\hline
\end{tabular}

${ }^{\mathrm{z}}$ All coefficients are significant at $P<0.0001$.

A

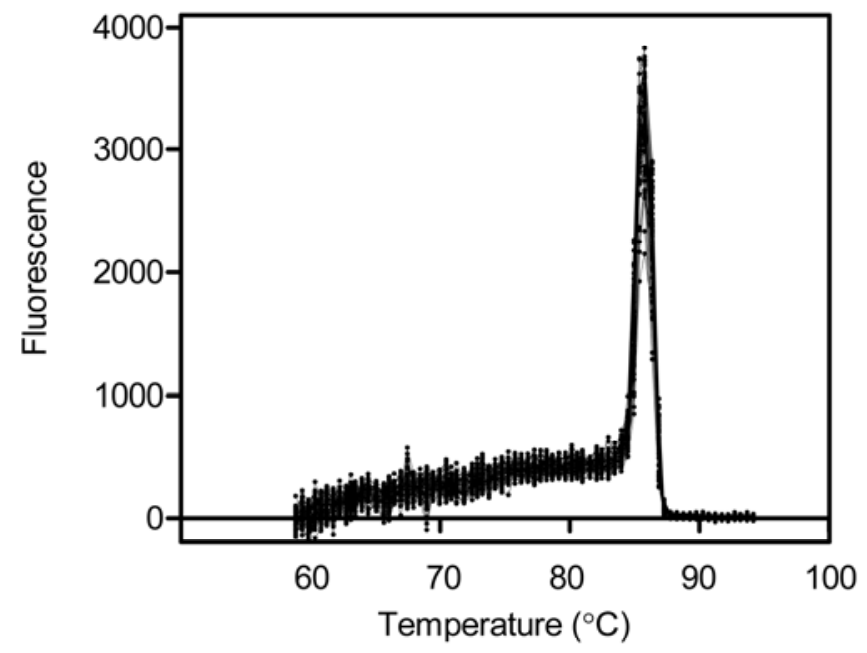

$\mathrm{C}$

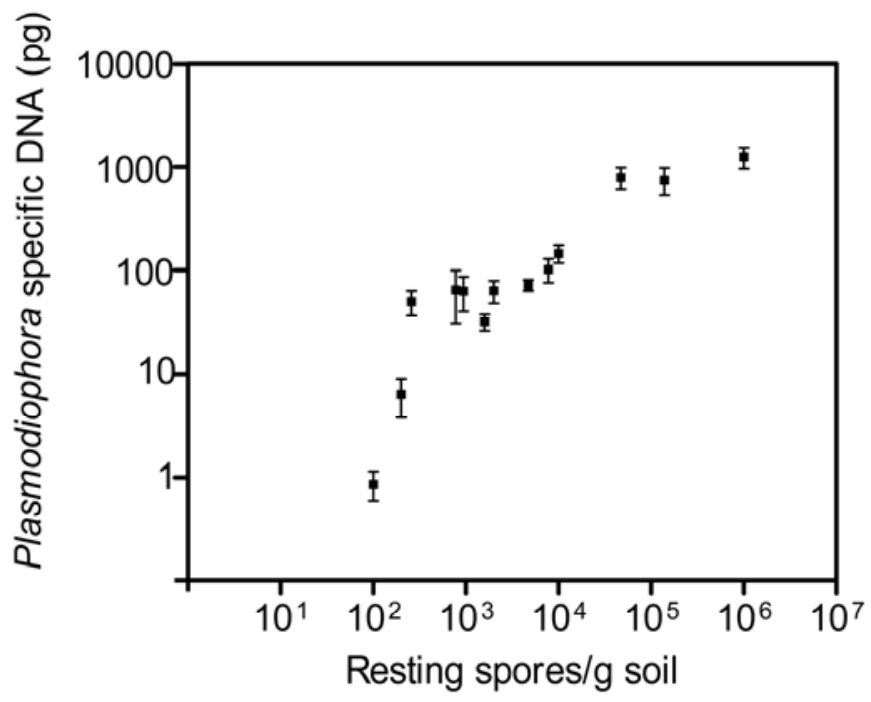

B
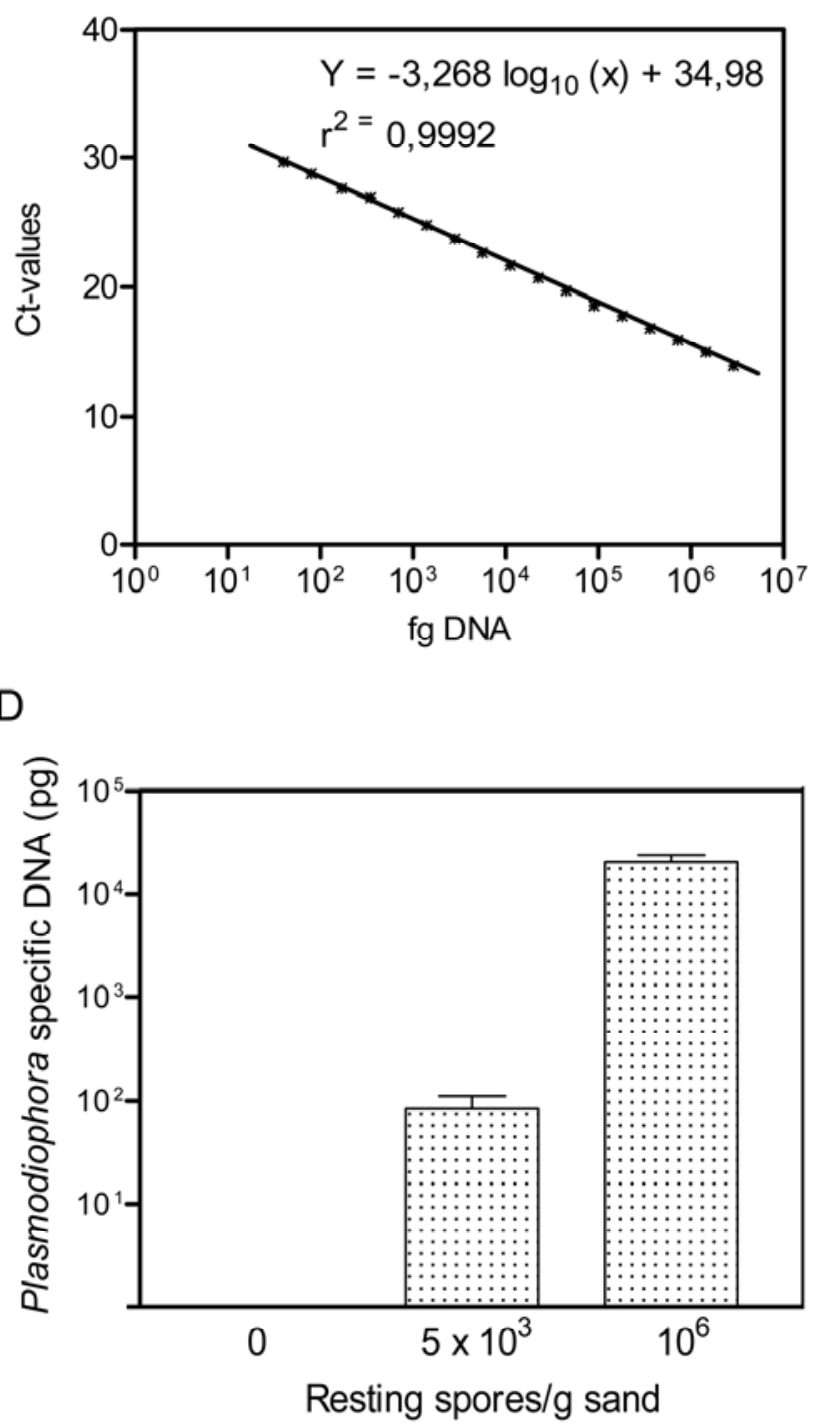

Fig. 4. Evaluation of the real-time polymerase chain reaction (PCR) primers Pb4-1 and PbITS6 and estimation of Plasmodiophora brassicae DNA amounts using real-time PCR. A, Melting curve. B, Standard curve. C, Estimation of P. brassicae DNA amounts in plant roots 35 days after sowing at increasing soil spore concentrations. D, $P$. brassicae DNA amounts in plant roots, grown in sand amended with $0,10^{3}$, and $10^{6}$ resting spores per gram, 10 days after sowing. 
proximately 185 copies in fungi (10) and, therefore, is an excellent target for PCR. The real-time PCR primers used in this study, Pb4-1 and PbITS6, only amplified a product from $P$. brassicae and could easily detect the pathogen in plants 10 days after germination, which is considerably better than the primers $\mathrm{Pb}$-act 1 and $\mathrm{Pb}$-act 2 that were not able to detect $P$. brassicae until 20 days after infection (25). This early detection makes it possible to measure the level of infection before visible symptoms have developed. Faggian et al. (6) found the detection limit of their nested PCR to be $0.1 \mathrm{fg}$ using primers designed in the ITS region and pure $P$. brassicae DNA. In comparison, the real-time assay presented here had a detection limit of $4.1 \mathrm{fg}$ of pure $P$. brassicae DNA but the risk of contaminating samples during reaction set up is considerably smaller in real-time assays than in nested PCR assays (17).

The in planta quantification of $P$. brassicae DNA and ARA using real-time PCR and WCFA measurements showed a good correlation with the soil spore content; therefore, both methods have the potential to be used in standardized assays estimating the soil spore content of naturally infested soils.

Instead of measuring the amount of $P$. brassicae directly in the soil, we monitored the amount of $P$. brassicae in plants. This bioamplification ensured that the measured level of $P$. brassicae reflects the disease-causing potential present in the soil because only viable spores are detected. DNA extraction directly from soil has also been shown to be problematic, because different soil types demand different DNA extraction methods (35). Furthermore, the bioamplification enhances the sensitivity of the assay. This was supported by results obtained with standard PCR and agarose gels using the primers PbITS6 and PbITS7. Using these primers and a bioamplification step, we could detect 100 spores/g of soil (results not shown) whereas Faggian et al. (6) found the detection limit to be 1,000 spores/g of soil using the same primers in a nested PCR when extracting DNA from soil. The main disadvantage of using the bioamplification step is that it is time consuming but, using real-time PCR, the growth period could possibly be shortened, because we were already able to detect $P$. brassicae 10 days after germination of the plants.

Until now, molecular and biochemical methods have only been able to show whether or not $P$. brassicae is present in a sample; however, here, we present two methods, real-time PCR and WCFA analysis, making it possible to show to what extent the pathogen is present. We now have tools making it possible to quantify $P$. brassicae during plant infection at different environmental conditions and during interaction with other organisms. Both methods can also be used in resistance screens, being superior to both DI and DSS. In controlled experimental systems, WCFA analysis is a promising method for simultaneous quantification of $P$. brassicae and other microorganisms.

\section{ACKNOWLEDGMENTS}

We thank the Danish Research Centre for Organic Food and Farming for financial support concerning the DARCOF II project VegCatch, the Danish Agricultural and Veterinary Research Council for financial support of the project "Secretome analysis of plant pathogen interactions, based on transposon assisted signal trapping," and T. Tønnersen and S. Meier for technical support.

\section{LITERATURE CITED}

1. Bååth, E. 2003. The use of neutral lipid fatty acids to indicate the physiological conditions of soil fungi. Microb. Ecol. 45:373-383.

2. Buczacki, S. T. 1983. Plasmodiophora-an inter-relationship between biological and practical problems. Pages 161-191 in: Zoosporic Plant Pathogens-A Modern Perspective. S. T. Buczacki, ed. Academic Press, London.

3. Buczacki, S. T., Toxopeus, H., Mattusch, P., Johnston, T. D., Dixon, G. R., and Hobolth, L. A. 1975. Study of physiologic specialization in Plasmodiophora brassicae: proposals for attempted rationalization through an international approach. Trans. Br. Mycol. Soc. 65:295-303.

4. Cao, T., Tewari, J., and Strelkov, S. E. 2007. Molecular detection of Plasmodiophora brassicae, causal agent of clubroot of crucifers, in plant and soil. Plant Dis. 91:80-87.

5. Colhoun, J. 1957. A technique for examining soil for the presence of Plasmodiophora brassicae Woron. Ann. Appl. Biol. 45:559-565.

6. Faggian, R., Bulman, S. R., Lawrie, A. C., and Porter, I. J. 1999. Specific polymerase chain reaction primers for the detection of Plasmodiophora brassicae in soil and water. Phytopathology 89:392-397.

7. Faggian R., and Strelkov, S. E. 2009. Detection and Measurement of Plasmodiophora brassicae. J. Plant Growth Regul. 28:282-288.

8. Ghandi, S. R., and Weete, J. W. 1991. Production of the polyunsaturated fatty acids arachidonic and eicosapentaenoic acid by the fungus Pythium ultimum. J. Gen. Microbiol. 137:1825-1830.

9. Ito, S., Maehara, T., Maruno, E., Tanaka, S., Kameya-Iwaki, M., and Kishi, F. 1999. Development of a PCR-based assay for the detection of Plasmodiophora brassicae in soil. J. Phytopathol. 147:83-88.

10. Krumlauf, R., and Marzluf, G. A. 1980. Genome organization and characterization of the repetitive and inverted repeat DNA sequences in Neurospora crassa. J. Biol. Chem. 10:11381145.

11. Lange, L., Heide, M., Hobolth, L., and Olson, L. W. 1989. Serological detection of Plasmodiophora brassicae by dot immunobinding and visualization of the serological reaction by scanning electron microscopy. Phytopathology 79:1066-1071.

12. Larsen, J., and Bødker, L.. 2001. Interactions between pea root-inhabiting fungi examined using signature fatty acids. New Phytol. 149:487-493

13. Larsen J., Mansfeld-Giese, K., and Bødker, L. 2000. Quantification of Aphanomyces euteiches in pea roots using specific fatty acids. Mycol. Res. 104:858-864

14. Lechevalier, H., and Lechevalier, M. P. 1988. Chemotaxonomic use of lipids-an overview. Pages 869-902 in: Microbial Lipids, Volume 1. C. Ratledge and S. G. Wilkinson, eds. Academic Press, New York

15. Ludwig-Müller, J. 1999. Plasmodiophora brassicae, the causal agent of clubroot disease; a review on molecular and biochemical events in pathogenesis. J. Plant Dis. Prot. 106:109127.

16. MacFarlane, I. 1952. Factors affecting the survival of Plasmodiophora brassicae Wor. in the soil and its assessment by a host test. Ann. Appl. Biol. 39:239-256.

17. McCartney, H. A., Foster, S. J., Fraaije, B. A., and Ward, E. 2003. Molecular diagnostics for fungal plant pathogens. Pest Manage. Sci. 59:129-142.

18. Melville, S. C., and Hawken, R. H. 1967. Soil testing for club root in Devon and Cornwall. Plant Pathol. 16:145-147.

19. Morin, H., Tremblay, M.-H., Plante, E., and Paré, C. 2007. High avidity binding of engineered Papaya mosaic virus virus-like particles to resting spores of Plasmodiophora brassicae. J. Biotechnol. 128:423-434.

20. Okubara, P. A., Schroeder, K. L., and Paulitz, T. C. 2005. Real-time polymerase chain reaction: applications to studies on soilborne pathogens. Can. J. Plant Pathol. 27:300-313.

21. Olsson, P. A. 1999. Signature fatty acids provide tools for determination of the distribution and interactions of mycorrhizal fungi in soil. FEMS Microbiol. Ecol. 29:303-310.

22. Ratledge, C., and Wilkinson, S. G. 1988. Fatty acids, related and derived lipds. Pages 2-53 in: Microbial Lipids, Vol. I. C. Ratledge and S. G. Wilkinson, eds. Academic Press, London.

23. Ratti, C., Budge, G., Ward, L., Clover, G., Rubies-Autonell, C., and Henry, C. 2004. Detection and relative quantification of Soilborne cereal mosaic virus (SBCMV) and Polymyxa graminis in winter wheat using realtime PCR (TaqMan). J. Virol. Methods 122:95103.

24. Sasser, M. 1990. Identification of bacteria through fatty acid analysis. Pages 199-204 in: Methods in Phytobacteriology. Z. Clement, K. Rudolph, and D. C. Sands, eds. Akadémiai Kiadó, Budapest.

25. Schuller, A., and Ludwig-Müller, J. 2006. A family of auxin conjugate hydrolases from Brassica rapa: characterization and expression during clubroot disease. New Phytol. 171:145158.

26. Takahashi, K., and Yamaguchi, T. 1989. Assessment of pathogenicity of resting spores of Plasmodiophora brassicae in soil by fluorescence microscopy. Ann. Phytopathol. Soc. Jpn. 55:621-628.

27. Thornton, C. R., Jarvis, B. C., and Cooke, R. C. 1991. A chitin assay for the enumeration of Plasmodiophora brassicae resting spores in clubroot tissue. Mycol. Res. 95:879-882.

28. Thygesen K., Larsen, J., and Bødker, L. 2004 Arbuscular mycorrhizal fungi reduce development of pea root-rot caused by Aphanomyces euteiches using oospores as pathogen inoculum. Eur. J. Plant Pathol. 110:411-419.

29. Tunlid, A., and White, D. C. 1992. Biochemical analysis of biomass, community structure, nutritional status, and metabolic activity of microbial communities in soil. Pages 229-262 in: Soil Biochemistry, vol. 7. G. Stotzky and J.-M. Bollag, eds. Marcel Dekker, New York.

30. van de Graf, P., Lees, A. K., Cullen, C. W., and Duncan, J. M. 2003. Detection and quantification of Spongospora subterranea in soil, water and plant tissue samples using real-time PCR Eur. J. Plant Pathol. 109:589-597.

31. Voorrips, R. E., and Kanne, H. J. 1997. Genetic analysis of resistance to clubroot (Plasmodiophora brassicae) in Brassica oleracea. I. Analysis of symptom grades. Euphytica 93:3139.

32. Wakeham, A. J., and White, J. G. 1996. Serological detection in soil of Plasmodiophora brassicae resting spores. Physiol. Mol. Plant Pathol. 48:289-303.

33. Wallenhammar, A.-C. 1996. Prevalence of Plasmodiophora brassicae in a spring oilseed 
rape growing area in central Sweden and factors influencing soil infestation levels. Plant Pathol. 45:710-719.

34. Wallenhammar, A.-C. 1998. Observations on yield loss from Plasmodiophora brassicae infections in spring oilseed rape. Z. Pflanzenkrankh. Pflanzenschutz-J. Plant Dis. Prot.
105:1-7.

35. Wallenhammar, A.-C., and Arvidsson, O. 2001. Detection of Plasmodiophora brassicae by PCR in naturally infested soils. Eur. J. Plant Pathol. 107:313-321.

36. Ward, L. I., Beales, P. A., Barnes, A. V., and Lane, C. R. 2004. A real-time PCR assay based method for routine diagnosis of Spongospora subterranea on potato tubers. J. Phytopathol 152:633-638.

37. Weete J. D., Fuller, M. S., Huang, M. Q., and Gandhi, S. R. 1989. Fatty-acids and sterols of selected Hyphochytriomycetes and Chytridiomycetes. Exp. Mycol. 13:183-195. 